\title{
Heat shock protein GroE of Escherichia coli: key protective roles against thermal stress
}

\author{
Noriko Kusukawa and Takashi Yura ${ }^{1}$ \\ Institute for Virus Research, Kyoto University, Kyoto 606, Japan
}

\begin{abstract}
An Escherichia coli mutant lacking the heat shock $\sigma$-factor $\left(\sigma^{32}\right)$ is defective in transcription from heat shock promoters and cannot grow at temperatures above $20^{\circ} \mathrm{C}$. To assess physiological roles of $\sigma^{32}$ and heat shock proteins, we isolated and characterized a set of temperature-resistant revertants from this deletion $(\Delta r p o H)$ mutant. Most of them were found to carry a DNA insertion in the groE upstream region, resulting in high-level synthesis of major heat shock proteins GroE (GroES and GroEL). The levels of GroE produced varied in different revertants and correlated well with the maximum permissive temperatures; the highest GroE producers $\sim \sim 10 \%$ of total protein) grew up to $40^{\circ} \mathrm{C}$ but not at $42^{\circ} \mathrm{C}$. An additional mutation causing hyperproduction of DnaK (hsp70 homolog) was required for growth at $42^{\circ} \mathrm{C}$. Such effects of GroE and DnaK on the $\sigma^{32}$-deletion strains were also confirmed by using multicopy plasmids carrying groE or dnaK. Thus, GroE plays a key protective role in supporting growth at normal physiological temperatures $\left(20-40^{\circ} \mathrm{C}\right)$, whereas high levels of DnaK are required primarily at higher temperature.
\end{abstract}

[Key Words: Heat shock response; heat shock protein; $\boldsymbol{\sigma}$ factor; GroE protein; DnaK protein; bacterial growth]

Received March 17, 1988; revised version accepted April 14, 1988.

A specific set of heat shock proteins (hsps) is markedly induced when cells are exposed to higher temperature. Such induction of hsps has been found virtually in all organisms (Schlesinger et al. 1982). About 20 hsps are known in Escherichia coli (Neidhardt et al. 1984); among them DnaK and C62.5 are highly homologous to eukaryotic hsp70 and hsp83, respectively (Bardwell and Craig 1984, 1987). GroEL was recently shown to be structurally related to a mitochondrial hsp58 of several eukaryotic species (McMullin and Hallberg 1988). As in eukaryotes, E. coli hsps are induced not only by thermal stress but also by other agents (see Neidhardt et al. 1984; Neidhardt and VanBogelen 1987), implying that hsps play some protective functions. Many of the hsps are implicated in the synthesis, assembly, and turnover of nucleic acids and proteins, but their precise roles in bacterial growth remain unknown.

The heat shock induction in $E$. coli is achieved by increasing transcription of hsp genes (Yamamori and Yura 1980 ), and is mediated by the product of a regulatory gene (rpoH, htpR, hin) (Neidhardt and VanBogelen 1981; Yamamori and Yura 1982), now identified as a minor $\sigma$ factor $\left(\sigma^{32}\right)$ (Grossman et al. 1984; Landick et al. 1984; Yura et al. 1984). Transcription initiated at the heat shock promoters is markedly but transiently enhanced by exposure to higher temperature (Grossman et al. 1984; Taylor et al. 1984; Cowing et al. 1985), presumably due

${ }^{1}$ Corresponding author. to rapid and transient increase in the $\sigma^{32}$ level (Grossman et al. 1987; Skelly et al. 1987; Straus et al. 1987).

The $\sigma^{32}$-mediated transcription of hsp genes not only plays an important role in the heat shock response but also in normal balanced growth of $E$. coli, because $r p o H$ null mutants lacking $\sigma^{32}$ cannot grow at temperatures above $20^{\circ} \mathrm{C}$ (Zhou et al. 1988). Analysis of hsp transcripts in these mutants indicated that $\sigma^{32}$ is solely responsible for transcription from heat shock promoters. Although the physiological significance of the heat shock response is not well understood, the maintenance of steady-state hsp levels and their control upon heat shock is clearly important for normal cell growth, as well as for survival at extreme temperatures.

The isolation and characterization of the temperatureresistant suppressor of the $\Delta r p o H$ strain has allowed us to further dissect the role of hsps during balanced growth. The majority of the single-step revertants exhibited elevated synthesis of the GroES and GroEL proteins. The maximum permissive growth temperature of each revertant correlated well with the amount of GroE proteins produced, suggesting that the enhanced synthesis of two (GroES and GroEL) out of some 20 hsps affected by the $\Delta r p o H$ mutation compensated effectively for the lack of $\sigma^{32}$ in sustaining cell growth at the normal temperature range $\left(20-40^{\circ} \mathrm{C}\right)$. Enhanced synthesis of another hsp (DnaK protein), in addition to GroE, supported growth of the $\Delta r p o H$ strain at temperatures higher than those attained by GroE alone. 


\section{Results}

Isolation of temperature-resistant revertants from $\sigma^{32}$ deletion $(\Delta \mathrm{rpoH})$ mutant

As reported elsewhere (Zhou et al. 1988), we have constructed $\sigma^{32}$ deletion mutants by replacing most of the coding region of the chromosomal $r p o H$ by a kanamycin-resistance gene. The deletion $(\Delta r p o H)$ strains grow at or below $20^{\circ} \mathrm{C}$ but not at higher temperatures, and no hsp induction is observed upon temperature upshift. Spontaneous temperature-resistant revertants were obtained from the deletion mutant by one-step selection at $30,34,37$, and $40^{\circ} \mathrm{C}$, but not at $42^{\circ} \mathrm{C}$. The reversion frequencies were inversely correlated with the temperature used $\left(10^{-7}\right.$ to $\left.10^{-9}\right)$. Revertants that can grow at $42^{\circ} \mathrm{C}$ were obtained by a two-step selection at $30^{\circ} \mathrm{C}$ and then at $42^{\circ} \mathrm{C}$; these revertants therefore carry at least two mutations (see below). The revertants were tested for their viability at different temperatures and grouped into four classes (Fig. 1; e.g., R30 designates revertants that grow up to $\left.30^{\circ} \mathrm{C}\right)$. R 40 revertants exhibited the highest thermoresistance among the single-step revertants and were analyzed most extensively. In peptone (P) broth, R40 grew exponentially at temperatures between 25 and $37^{\circ} \mathrm{C}$, and the doubling times were 1.4- to 1.7-fold longer than those for wild type $\left(\mathrm{rpoH}^{+}\right)$. At temperatures above $40^{\circ} \mathrm{C}$, they grew into long filaments and gradually lost viability (Fig. 2). R40 revertants such as KY1603 exhibited slightly cold-sensitive growth, i.e., very slow growth at $20^{\circ} \mathrm{C}$, particularly in minimal medium.

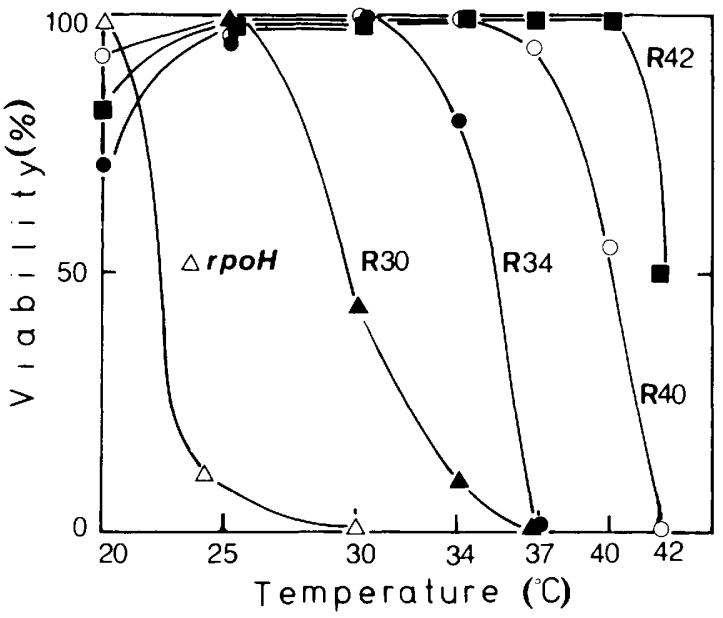

Figure 1. Temperature profile of viability for representative classes of revertants. Exponentially growing cultures at $20^{\circ} \mathrm{C}$ (for $\Delta$ rpoH and R30) or at $30^{\circ} \mathrm{C}$ (for R34, R40, and R42) were diluted and plated onto $P$ agar and incubated at the temperatures indicated. The number of colony formers was counted after $24-72 \mathrm{hr}$ (depending on the incubation temperature) and normalized to the value at an optimum temperature for each strain.

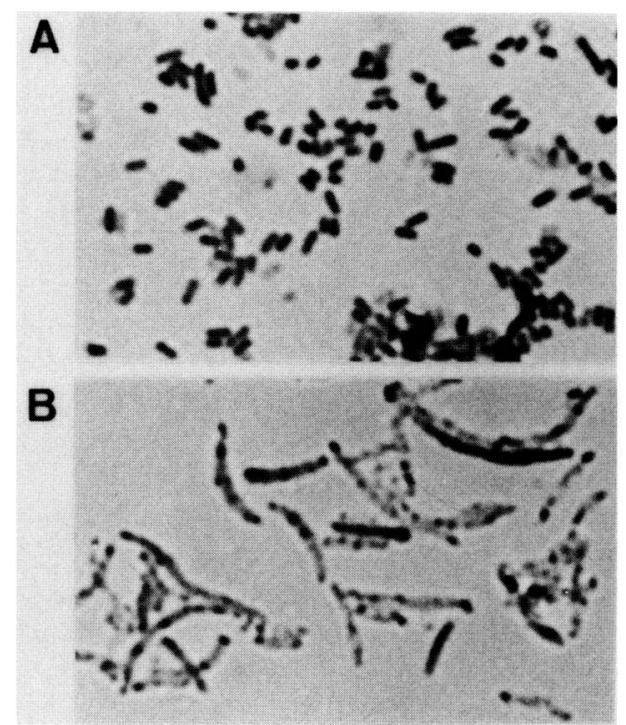

Figure 2. Morphology of R40 revertant cells. Cells of KY1603 growing exponentially in $\mathrm{L}$ broth at $37^{\circ} \mathrm{C}(A)$ or after incubation at $42^{\circ} \mathrm{C}$ for $4 \mathrm{hr}(B)$ were collected, spread onto microslides, and stained with Eosin-Giemsa. Cells of wild-type MC4100 grown at 37 or $42^{\circ} \mathrm{C}$ were essentially identical to those of $\mathrm{R} 40$ at $37^{\circ} \mathrm{C}$ (not shown).

\section{Constitutive synthesis of GroE proteins}

The dramatic suppression of temperature-sensitive growth by R40 reversions suggested that these revertants might also respond to heat shock. Twenty independently isolated R40s were examined for protein synthesis at $30^{\circ} \mathrm{C}$ and after shift to $42^{\circ} \mathrm{C}$. None of the revertants exhibited heat-shock-dependent increase in the synthesis rates of hsps (87K, DnaK, GroEL, etc.). The response of one particular mutant R40-1 to temperature upshift is displayed in Figure 3A. In R40-1, and in all other revertants, the synthesis rate of a $64-\mathrm{kD}$ protein was higher than that in the wild type, both at 30 and $42^{\circ} \mathrm{C}$. This protein was identified as one of the major hsps, GroEL, by immunoprecipitation (Fig. 3B).

The enhanced synthesis of GroE in suppressor strains could result from a new cis-acting regulatory region located upstream to groE. Alternatively, the suppressor could affect a trans-acting factor that stimulated the expression of groE. Experiments using R40 revertants lysogenic for a recombinant $\lambda$ phage carrying $l a c Z$ fused to the groE promoter ( $\lambda \mathrm{pF} 13$-PgroE-lacZ) ruled out the second possibility, because the levels of $\beta$-galactosidase activities, both at $30^{\circ} \mathrm{C}$, and after shift to $42^{\circ} \mathrm{C}$, were lower than in the wild-type background. If a trans-acting factor were affected, the groE promoter activity determined by $\beta$-galactosidase would have been higher than in the wild type.

\section{Suppressors map at the groE region on the chromosome}

P1 phage-mediated transduction experiments revealed that the mutation sites in R40 revertants lie near groE. 
Tetracycline-resistance transposons zje:: Tn10 and zje1 :: Tn10, located on the opposite sides of groE lat roughly the same distance from the structural genel, were transduced from an otherwise wild-type donor into three independently isolated R40 revertants. Among the tetracycline-resistant transductants selected at $20^{\circ} \mathrm{C}$, $\sim 50 \%$ were temperature sensitive /nonviable at or above $30^{\circ} \mathrm{Cl}$, which agreed with the known cotransduction frequencies between groE and the Tn10s. Similar experiments with one of the R30 revertants gave identical results. The suppressor locus in the R40 and R30 revertants was designated suhX and localized at or around the groE operon.

We then cloned the groE region from the chromosome of R40s (R40-1, R40-2, and R40-3) and examined the mutation sites more closely. The groE operon, located on an $8 \mathrm{~kb}$ EcoRI fragment, contains two adjacent genes, groES and groEL (Tilly et al. 1981), that are transcribed from two promoters located upstream of groES (Zhou et al. 1988). The two promoters, groES, and part of groEL are contained in a 2-kb EcoRV fragment (Fig. 4A). Chromosomal DNAs from R40s were digested with EcoRI or EcoRV, joined with pBR322, and recombinant plasmids that complement the temperature-sensitive phenotype of groES619 or groEL44 strains were selected. Examination of the cloned DNAs by restriction enzymes revealed that the sizes of the EcoRI fragment and the EcoRV fragment derived from R40s were 9 and $1.75 \mathrm{~kb}$, respectively, clearly different from those of the respective fragments from wild type. Further experiments established that the chromosomes from all R40s tested

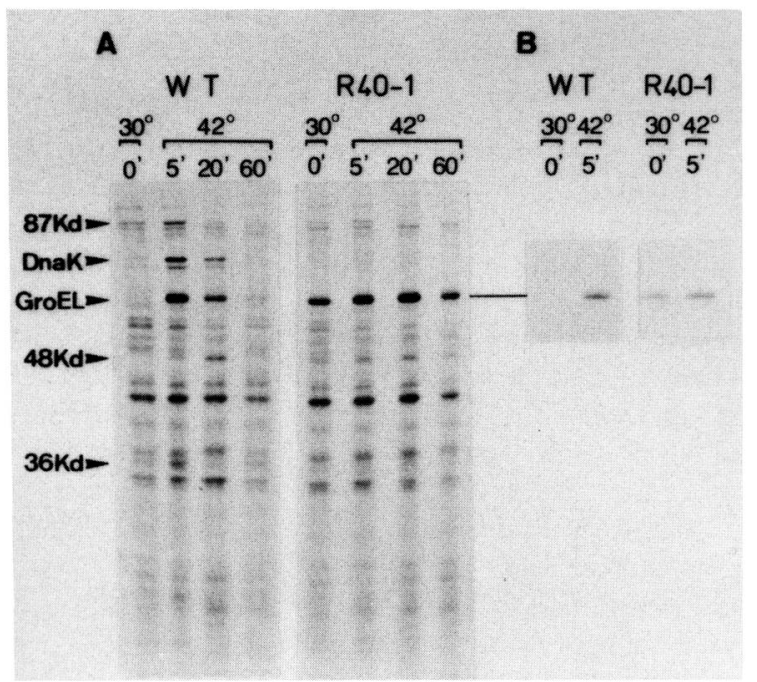

Figure 3. Polyacrylamide gel electrophoresis of proteins. $(A)$ Log-phase cells grown in minimal medium were pulse-labeled with $\left[{ }^{35} \mathrm{~S}\right]$ methionine for $3 \mathrm{~min}$ at $30^{\circ} \mathrm{C}$ or after shift to $42^{\circ} \mathrm{C}$ for 5,20 , and $60 \mathrm{~min}$. Whole-cell proteins were analyzed by SDSgel electrophoresis $\left(10^{5} \mathrm{cpm} / \mathrm{lane}\right)$. Arrowheads indicate bands (hsps) that are transiently enhanced by temperature shift in the wild-type MC4100 (WT). (B) Labeled proteins from $A$ were treated with antiserum against GroEL, and the precipitates were electrophoresed as in $A$.

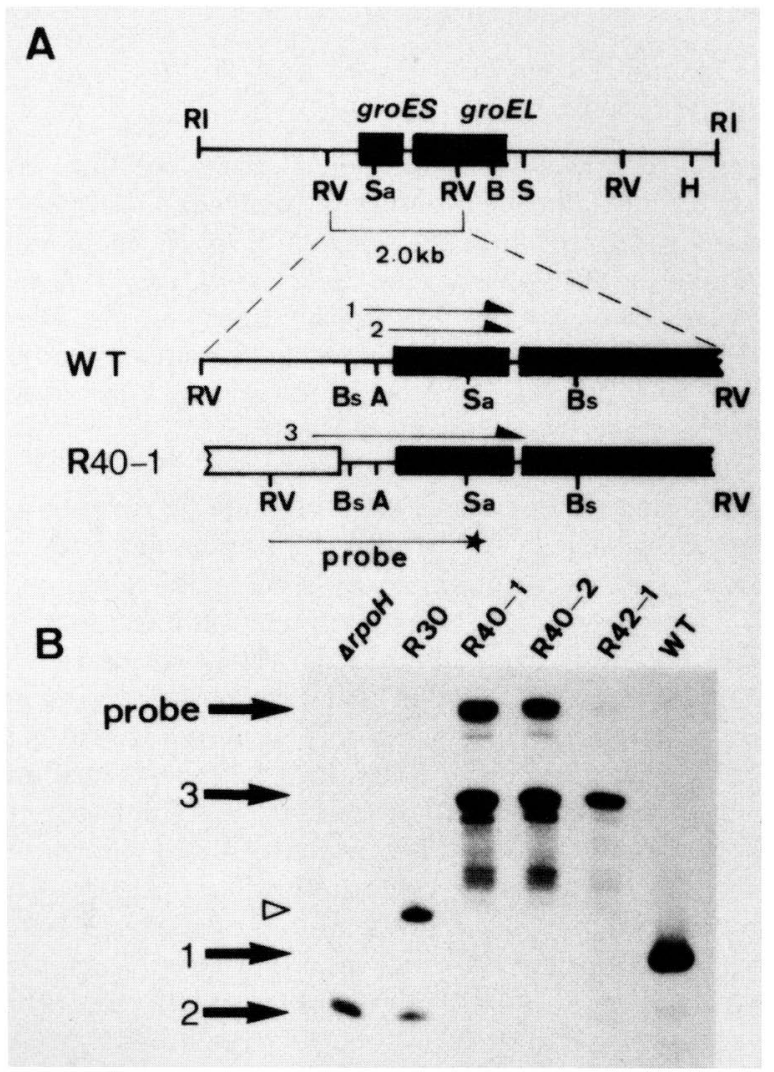

Figure 4. DNA structure and transcription of the groE region. (A) Physical map of the groE region. Solid boxes indicate the groE genes; the open box represents an insertion on the chromosome of R40-1 (KY1603). Arrows indicate the start points of groE transcripts. (A) AhaII; (B) BamHI; (Bs) BstEII; (RI) EcoRI; (RV) EcoRV; (H) HindIII; (S) SmaI; (Sa) SacII. (B) Nuclease S1 mapping of groE mRNAs. RNAs were extracted from log-phase cells grown in $\mathrm{L}$ broth at $30^{\circ} \mathrm{C}\left(20^{\circ} \mathrm{C}\right.$ for the $\Delta r p o H$ parent $)$ and hybridized with probe DNA derived from the R40-1 chromosome shown in $A$ ( $5^{\prime}$ labeled at the SacII site). Arrows indicate positions of messengers transcribed from the major heat shock promoter (1), a minor $\sigma^{70}$ promoter (2), or a new promoter seen in R40s (3) and undigested probe. The open arrowhead indicates the endpoint of $g r o E$ upstream sequence joined to the insertion on the R40 (and presumably R30 and R42) chromosome, based on the results of Figure 5B. Data for R40-3 and R42-2 are not shown.

contained a $1-\mathrm{kb}$ insertion located upstream of the groE heat shock promoter (1) (see Fig. 4A). The EcoRI fragment from the $\mathrm{R} 30$ revertant was also larger than that from wild type, indicating that a suppressor affected the groE region.

\section{groE transcription starts from within the insertion}

To examine whether the insertions affected the groE transcription, we determined the start points of groE mRNA in the revertants by nuclease S1 mapping. The promoter-proximal region (EcoRV-SacII fragment) of 
groE DNA obtained from R40-1 (KY1603) was initially used as a hybridization probe. As seen in Figure $4 \mathrm{~B}$, groE mRNA in the wild type was mostly transcribed from the heat shock promoter (promoter 1), whereas in the $\Delta r p o H$ revertants it was transcribed from new start points. In the three R40s, a start point (promoter 3) was found within the insertion at about 100 bases upstream from the junction (the junction was verified by S1 mapping using wild-type groE DNA as a probe; an example is seen in Fig. 5). Substantial amounts of undigested probe were

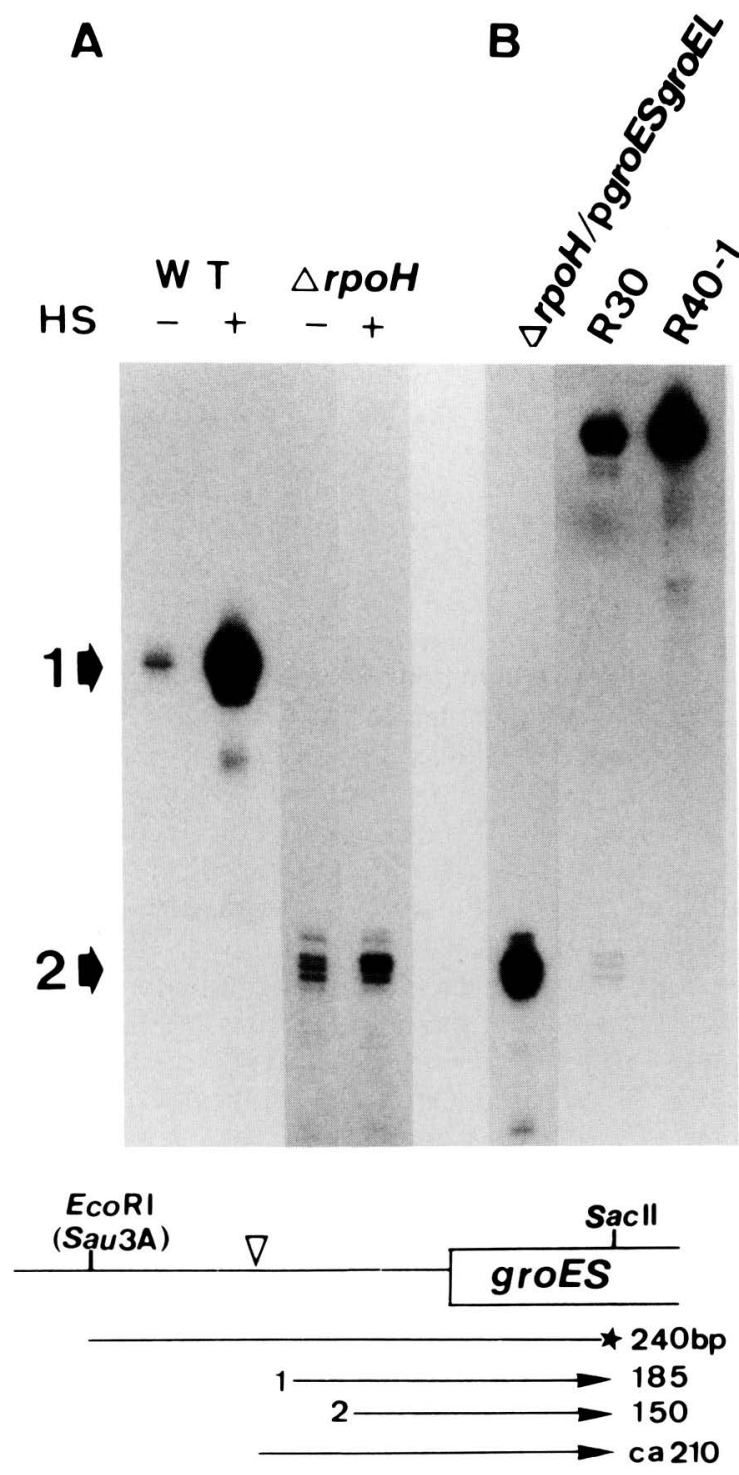

Figure 5. Quantitation of groE mRNA levels. Log-phase cells grown in $\mathrm{L}$ broth at the temperature indicated or after transfer to $42^{\circ} \mathrm{C}$ were used for RNA extraction. RNAs $(40 \mu \mathrm{g})$ were hybridized with excess 5 '-labeled wild-type groE promoter region (EcoRI-SacII fragment) and subjected to quantitative nuclease $\mathrm{S} 1$ protection. Arrows indicate mRNAs initiated from promoter 1 or 2, and the open arrowhead shows the endpoint of the groE upstream sequence, as in Figure 4B. (A) Wild-type MC4100 and $\Delta r p o H$ mutant cells at $20^{\circ} \mathrm{C}$ or after heat shock (HS) at $42^{\circ} \mathrm{C}$ for $15 \mathrm{~min} .(B)$ The $\Delta$ ppoH/pgroESgroEL strain and R30 or R40 revertants grown at $30^{\circ} \mathrm{C}$. seen in R40s suggesting the presence of additional transcript/s) initiated from farther upstream. Thus, the elevated levels of groE mRNA seem to be attributable to these multiple transcripts. Three independently isolated R40s were examined and gave virtually identical results. The R30 revertant (KY1615) gave a new start point that probably reflects a structural alteration that is distinct from those seen in R40s. The R42 revertants that were obtained by two-step selections at $30^{\circ} \mathrm{C}$ and then at $42^{\circ} \mathrm{C}$ produced moderate amounts of $g r o E$ transcript different from R30 but similar to the transcript from promoter 3 found in R40s.

In $\Delta r p o H$ strains, groE transcript initiates at a downstream promoter (promoter 2 in Fig. 4B), known to be transcribed by RNA polymerase containing $\sigma^{70}$ (Zhou et al. 1988). This is a weak promoter and virtually inactive in $\mathrm{R} 40 \mathrm{~s}$ or in the $r p o H^{+}$strain, presumably due to interference by strong transcription from upstream promoters.

Suppression of the $\Delta \mathrm{rpoH}$ mutant by plasmids carrying groE

The above results strongly suggest that the cellular level of GroE protein(s) is critical when cells lacking $\sigma^{32}$ are exposed to higher temperature. We then introduced multicopy plasmids carrying part or whole of the $g r o E$ operon into the $\triangle r p o H$ mutant. In these strains, groE transcription on the plasmid should occur only from promoter 2, but might cause synthesis of GroE proteins sufficient to suppress the temperature-sensitive growth. Indeed, a plasmid carrying both groES and groEL (pgroESgroEL) supported growth of the $\triangle r p o H$ strain up to $37-40^{\circ} \mathrm{C}$ (Table 1 ). The plasmid carrying only groES was less effective but supported growth up to $34^{\circ} \mathrm{C}$. In contrast, a plasmid containing only intact groEL was hardly effective, though this could be due to a lower copy number of the plasmid used.

Introduction of pgroESgroEL into R40 revertants inhibited rather than stimulated growth at all permissive temperatures $\left(20-40^{\circ} \mathrm{C}\right)$ and failed to support growth at $42^{\circ} \mathrm{C}$. The growth inhibition was particularly marked at $20^{\circ} \mathrm{C}$ in the presence of selective antibiotic, and transfer of cells to a nonselective medium caused rapid loss of the plasmid. It should be recalled that R40 itself shows slightly cold-sensitive growth (see above).

The magnitude of GroE production correlates with the upper limit of growth temperature

The correlation between the GroE levels and upper limits of growth temperature was explored by determining both $g r o E$ message and GroEL protein in various strains at different temperatures. The amount of groE mRNA was determined by nuclease $S 1$ protection, using excess 5'-labeled promoter-proximal region of wild-type groE DNA as a probe (Fig. 5). The groE mRNA in R40 at $30^{\circ} \mathrm{C}$ was very high and comparable to the heat-induced wild type. Much less but appreciable amounts of transcript from promoter 2 are seen in the $\triangle r p o H$ mutant carrying pgroESgroEL. The $\mathrm{R} 30$ revertant produced still 
Table 1. Growth of $\Delta \mathrm{rpoH}$ and R40-1 strains carrying a plasmid

\begin{tabular}{|c|c|c|c|c|c|c|c|c|}
\hline \multirow[b]{2}{*}{ Strain } & \multirow[b]{2}{*}{ Plasmid } & \multicolumn{7}{|c|}{ Growth at temperature $\left({ }^{\circ} \mathrm{C}\right)$} \\
\hline & & $\overline{20}$ & 25 & 30 & 34 & 37 & 40 & $\overline{42}$ \\
\hline \multirow{6}{*}{$\begin{array}{l}\Delta r p o H \\
\quad(\mathrm{KY} 1612)\end{array}$} & - & + & - & - & - & - & - & - \\
\hline & pgroESgroEL & + & + & + & + & + & \pm & - \\
\hline & pgroES & + & & + & + & - & - & - \\
\hline & pBR322 & + & - & - & - & - & - & - \\
\hline & $\mathrm{p}(\mathbf{P} t r p)-d n a K-\operatorname{Trp}$ & + & + & - & & & - & - \\
\hline & $+\operatorname{Trp}$ & + & - & - & & & - & - \\
\hline \multirow{6}{*}{$\begin{array}{l}\text { R40-1 } \\
\quad(\mathrm{KY} 1603)\end{array}$} & - & + & & + & ++ & ++ & ++ & - \\
\hline & pgroESgroEL & \pm & & + & + & + & + & - \\
\hline & pgroES & + & & + & ++ & ++ & ++ & - \\
\hline & pBR322 & + & & + & ++ & ++ & ++ & - \\
\hline & $\mathrm{p}(\mathrm{P} t r p)-d n a K-\operatorname{Trp}$ & + & + & + & & & + & + \\
\hline & $+\operatorname{Trp}$ & + & + & + & & & + & - \\
\hline
\end{tabular}

Log-phase cells grown in $\mathrm{P}$ broth containing ampicillin at $20^{\circ} \mathrm{C}\left(34^{\circ} \mathrm{C}\right.$ for $\mathrm{R} 40-1$ derivatives) were streaked onto $\mathrm{P}$ agar and incubated for $24-72 \mathrm{hr}$ at the temperatures indicated. Strains carrying $\mathrm{p}(\mathrm{P} t \mathrm{P} p)-d n a K$ were grown in minimal medium containing $0.2 \%$ casamino acids and chloramphenicol, diluted 100 -fold with fresh medium, with or without L-tryptophan $\{\operatorname{Trp}, 50 \mu \mathrm{g} / \mathrm{ml}$, and incubated for 24-72 hr. $1++\mid$ Normal growth; $\mid+$ or \pm ) good or fair growth; $|-|$ little or no growth. Each entry is based on the results for five independent transformants.

less mRNA. Thus, the cellular levels of groE mRNA may be lined in the following order: $\triangle r p o H \leq \mathrm{R} 30$ $\leqslant \triangle r p o H$ carrying pgroES-groEL $\leqslant \mathrm{R} 40$. This agrees well with the order of the maximum permissive temperature for these strains.

The cellular levels of GroE proteins during steadystate growth were then determined by immunoprecipitation with antiserum against GroEL (Table 2). The GroEL level in the $\triangle r p o H$ mutant is $\sim 50 \%$ of the wild type at $20^{\circ} \mathrm{C}$. All revertants of $\Delta r p o H$ and the $\Delta r p o H$ mutant carrying pgroESgroEL produced significantly more GroEL than the $\triangle r p o H$ parent, and the GroEL levels correlated well with the message levels, as expected. The GroEL level in R40 revertants was extremely high, amounting to $10 \%$ of total protein produced at $20^{\circ} \mathrm{C}$. Hyperproduction of GroES, as well as GroEL in R40s, has been confirmed by two-dimensional gel analysis of proteins (data not shown). We conclude that an enhanced synthesis of GroE proteins compensates effectively for the lack of $\sigma^{32}$ in supporting growth at the temperature range of $20-40^{\circ} \mathrm{C}$ in a dose-dependent fashion.

\section{DnaK protein helps growth at higher temperatures}

During analysis of heat shock gene expression in R42 revertants, we found appreciable amounts of dnaK
mRNA, in contrast to the $\Delta r p o H$ parent or other revertants. In the two $\mathrm{R} 42$ revertants tested, dnaK transcripts were apparently initiated from sites that were distinct from those for wild type (Fig. 6). In one strain (lane 6), the start site was located $\sim 10 \mathrm{bp}$ upstream of P1 (a major heat shock promoter), and in the other strain (lane 7), very close to a weak possible promoter (P3) (Cowing et al. 1985). The dnaK mRNA levels in R42 revertants at $30^{\circ} \mathrm{C}$ were comparable to that of wild type that had been heat shocked (lane 9). Enhanced synthesis of DnaK protein was also observed in these strains at 30 or $42^{\circ} \mathrm{C}$ (data not shown). Furthermore, P1 transduction experiments indicated that the ability of R42 strains to grow at $42^{\circ} \mathrm{C}$ was due to a mutation at the $d n a K$ region (perhaps a large insertion), designated suhY. Thus, the $\mathrm{R} 42$ revertants carry two suppressor mutations, one elevating groE expression (see Fig. 4B) and the other elevating dnaK expression by providing new promoters.

We then constructed a plasmid carrying $d n a K$ fused to the trp promoter and introduced it into the $\triangle r p o H$ mutant and the R40-1 revertant. As expected, R40 strains carrying the plasmid exhibited appreciable growth at $42^{\circ} \mathrm{C}$ when $d n a K$ was derepressed but not when $d n a K$ was repressed by tryptophan (Table 1). The production of DnaK regulated by tryptophan was confirmed by immunoprecipitation of labeled DnaK with a specific anti-

Table 2. Cellular contents of GroEL

\begin{tabular}{|c|c|c|c|c|}
\hline \multirow[b]{2}{*}{ Strain } & \multicolumn{3}{|c|}{ Relative content $\left({ }^{\circ} \mathrm{C}\right)$} & \multirow{2}{*}{$\begin{array}{l}\text { Max. permissive } \\
\text { temperature in } \\
\mathrm{P} \text { broth }\left({ }^{\circ} \mathrm{C}\right)\end{array}$} \\
\hline & 20 & 30 & 37 & \\
\hline $\mathrm{MC} 4100\left(\mathrm{rpoH}^{+}\right)$ & $0.60 \pm 0.08$ & $0.85 \pm 0.09$ & 1.00 & 45 \\
\hline 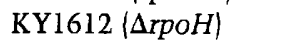 & $0.31 \pm 0.03$ & - & - & 20 \\
\hline KY1615 \{R30) & $0.58 \pm 0.07$ & $0.48 \pm 0.14$ & - & 30 \\
\hline KY1612/pgroESgroEL & $0.81 \pm 0.09$ & $0.99 \pm 0.14$ & $1.07 \pm 0.09$ & 37 \\
\hline KY1603 (R40-1) & $10.7 \pm 0.90$ & $8.41 \pm 1.5$ & $3.40 \pm 0.49$ & 40 \\
\hline KY1618 (R42-2) & - & - & $0.72 \pm 0.09$ & 43 \\
\hline
\end{tabular}

Log-phase cells grown in minimal medium at the temperatures indicated were labeled with [ ${ }^{35}$ S]methionine for two generations. GroEL was determined by immunoprecipitation, as described in Materials and methods. Values represent averages ( \pm S.D.) of five experiments and have been normalized to those of the wild type at $37^{\circ} \mathrm{C}$. 


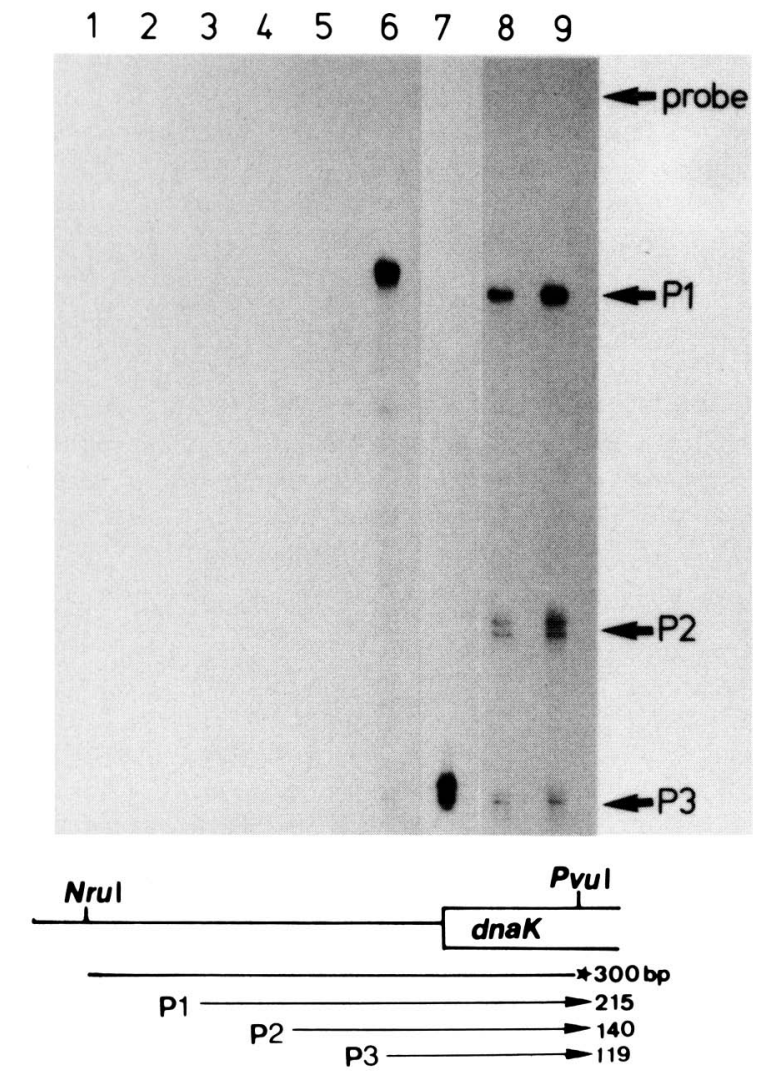

Figure 6. Nuclease $\mathrm{S} 1$ mapping of $d n a K$ mRNAs. RNAs were extracted from log-phase cells grown in $\mathrm{L}$ broth. The probe DNA was 5'-labeled NruI-PvuI fragment (comprising the dnaK promoter region) obtained from $\mathrm{pKV} 101 \mathrm{dnaK^{+ }}$. Hybridizations were carried out at $40^{\circ} \mathrm{C}$. (Lane 1) $\Delta$ ppoH KY1612 at $20^{\circ} \mathrm{C}$; (lane 2) $\Delta \mathrm{rpoH}, 15 \mathrm{~min}$ at $42^{\circ} \mathrm{C}$; (lane 3) $\Delta$ rpoH/pgroESgroEL at $30^{\circ} \mathrm{C}$; (lane 4) R30 at $30^{\circ} \mathrm{C}$; (lane 5) R40-1 at $30^{\circ} \mathrm{C}$; (lane 6) R42-1 at

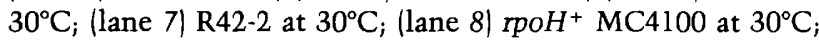
(lane 9 ) $\mathrm{rpoH}^{+}, 15 \mathrm{~min}$ at $42^{\circ} \mathrm{C}$.

serum. A similar effect of the plasmid was observed when it was introduced into the $\Delta r p o H /$ pgroESgroEL strain (data not shown). In contrast, the same plasmid stimulated growth of the $\Delta r p o H$ mutant only slightly at 20 or $25^{\circ} \mathrm{C}$. Thus DnaK is not as effective as GroE either in sustaining growth of the $\triangle r p o H$ mutant at low temperature or in raising the maximum permissive temperature. Rather, DnaK is more effective at higher temperatures $\left(37-42^{\circ} \mathrm{C}\right)$ or effective only when a certain threshold level of GroE is present.

\section{Discussion}

We have shown that the loss of $\sigma^{32}$ causing inability to grow at temperatures above $20^{\circ} \mathrm{C}$ could be effectively compensated with high-level production of a pair of GroE proteins. The ability to grow at temperatures up to $40^{\circ} \mathrm{C}$ was restored depending on the amounts of $\mathrm{GroE}$ synthesized; the higher the GroE level was, the higher the maximum permissive temperature. We thus propose that among the known set of about 20 hsps, GroE plays key protective roles in bacterial survival at a normal temperature range of $20-40^{\circ} \mathrm{C}$. This proposal rests on the assumption that the enhanced GroE level does not increase the synthesis of other hsps secondarily in the $\Delta r p o H$-derived strains. Two-dimensional gel analysis of proteins revealed that the levels of many hsps in the deletion mutant were low or hardly detectable at $20^{\circ} \mathrm{C}$ or after shift to higher temperature and were not increased appreciably in the R40-1 revertant that produces a huge excess of GroE or upon introduction of a groE plasmid into the $\triangle r p o H$ mutant (N. Kusukawa, unpubl.). On the other hand, alterations in the levels of several smallmolecular-weight proteins that are not hsps were noted in these strains. Hyperproduction of GroE might therefore affect the level of a number of proteins that are as yet poorly defined.

The nature of inserted DNAs causing hyperexpression of the groE operon in the revertants remains unknown. Perhaps the best candidate would be insertion sequence (IS) elements, because they often activate a downstream gene(s) due to a promoter within the elements (see Iida et al. 1983). The size of the inserts found in R40s is within the range expected for IS elements known to be present on the $E$. coli chromosome. The fact that several groE overexpressing revertants contained identical or nearly identical insertions suggests the involvement of insertion hot spot/s) at the groE upstream region. In fact, this region contains a 16-bp AT-rich sequence that may provide a favorable target for IS elements.

It has been reported that mutations in groEL or groES give similar phenotypes, i.e., defective phage morphogenesis (see Friedman et al. 1984) and defective DNA and RNA synthesis at high temperature (Wada and Ichikawa 1984). GroEL and GroES are also known to interact functionally in vivo and in vitro (see Friedman et al. 1984). Both proteins form oligomers separately and are found mostly in soluble fractions. Thus, the functions of the two GroE proteins are closely related but not interchangeable. In the present study, hyperproduction of GroES alone was partially effective in restoring growth of the $\Delta r p o H$ mutant (Table 1). The effect of excess GroEL alone has not been assessed unequivocally because the groEL plasmid used had a much lower copy number than the groES plasmid. Thus, the full protection against thermal damage may require interaction between GroEL and GroES, but partial protection appears to be achieved by GroES alone.

Although most GroEL proteins are found in soluble fractions, some GroEL seems to be associated with the $30 \mathrm{~S}$ ribosomal subunit in amounts that are growth-cycle dependent (Subramanian et al. 1976; Neidhardt et al. 1981) In phage $\lambda$ morphogenesis, GroEL plays an essential role in helping head assembly by forming an intermediate complex with the $\lambda \mathrm{B}$ protein (Georgopoulos et al. 1983|. Multicopy plasmids carrying groES and groEL were shown to suppress the temperature-sensitive growth of certain dnaA mutants defective in chromosomal DNA replication (Fayet et al. 1986; Jenkins et al. 1986). These results implicate structural rather than catalytic roles for GroE proteins in restoring various functions that would require complex macromolecular inter- 
actions. The present finding of dose-dependent protective roles for GroE is in good accord with such expectations. It is also consistent with the recently proposed general mechanism for eukaryotic hsp functions (Pelham 1986; Ellis 1987).

Like those in eukaryotes, hsps in E. coli are involved in a variety of distinct cellular processes, such as DNA replication, RNA synthesis, and protein synthesis and degradation (see Neidhardt et al. 1984). Although some hsps are known to have enzymatic functions, perhaps the basic mode of action common to many is to ensure that specific target proteins (or nucleic acids) are organized into proper conformations required for whatever reaction(s) that follows. Higher amounts of hsps are required at higher temperature, presumably because some of the hsps, notably GroE, are needed to protect the target macromolecules from forming abnormal or deleterious conformations that would become prevalent under stress conditions. It should be recalled that elevated synthesis of GroE (and DnaK) has not only been observed upon heat shock but also under other stress conditions such as UV irradiation, treatments with nalidixic acid and ethanol (Travers and Mace 1982; Krueger and Walker 1984), deprivation of carbon sources (Groat et al. 1986), and forced production of abnormal proteins (Goff and Goldberg 1985; Ito et al. 1986).

Although GroE and DnaK are the most abundant hsps in E. coli, dnaK null mutants that can grow at $30^{\circ} \mathrm{C}$ but not at $42^{\circ} \mathrm{C}$ have recently been isolated (Paek and Walker 1987). This indicates that DnaK is required for growth only at high temperature, though the possibility that such mutants quickly accumulate extragenic suppressors has not been excluded. Whether GroE is an absolute requirement below $20^{\circ} \mathrm{C}$ is not known. In the absence of $\sigma^{32}$, hyperproduction of GroE but not DnaK can support cell growth at $20-40^{\circ} \mathrm{C}$ (see Table 1), suggesting that the need for GroE predominates over that for DnaK at the normal physiological temperature range. At $42^{\circ} \mathrm{C}$, however, R40 revertants exhibit defective cell division and form filaments unless DnaK is supplied in trans, indicating that the cell requires DnaK function that cannot be satisfied by GroE. It is intriguing that GroE and DnaK play distinct roles that appear to be exerted at different stages (severity) of thermal stress.

Proteins homologous to GroEL appear to be present in organisms over a wide range of evolutionary distances. It has been found in bacteria other than $E$. coli (Carrascosa et al. 1982; Reuter and Shapiro 1987); a homopolymeric particle of 14 subunits $(67 \mathrm{kD})$, closely resembling GroEL oligomer, has been found in plant cells (Pushkin et al. 1982); and more recently an antigenically-related protein that can form similar oligomers was found in mitochondria of diverse organisms including Saccharomyces cerevisiae, Tetrahymena thermophila, Xenopus laevis, Zea mays, and human cells (McMullin and Halberg 1988). Thus, GroE homologs might be conserved evolutionarily, like hsp70, and further studies on GroE and DnaK functions should provide valuable insights into the role of hsps in general physiology of cell growth and response to environmental stress.

\section{Materials and methods}

Strains, phages, and plasmids

The E. coli strains used are listed in Table 3. Wild-type MC4100 and the rpoH deletion ( $\triangle \mathrm{rpoH} 30: \mathrm{kan}$ ) mutant KYl612 have been described (Zhou et al. 1988). KY1601 ( $\Delta r p o H)$ is isogenic with KY1612, except for the prophage it carries. The groE promoter region carried by $\lambda \mathrm{pF} 13-(\mathrm{PgroE}-\mathrm{lacZ})$ in $\mathrm{KY} 1612$ is longer (by $0.7 \mathrm{~kb}$ ) than that of the similar phage described by Yano et al. (1987). Plasmids pOF12 (pgroESgroEL), pJB8groES ${ }^{+}$, and pOF14 (pgroEL) were obtained from C. Georgopoulos, and pKV101dnaK ${ }^{+}$from R. Yano. p(Ptrp)-dnaK $K^{+}$(provided by $\mathrm{H}$. Nagai) was constructed by joining the intact $d n a K$ and part of $d n a /$ to the trp promoter on pSC101 carrying the cat gene.

\section{Media}

P broth and L broth have been described (Tobe et al. 1984). Minimal medium used was medium E (Vogel and Bonner 1956), supplemented with $0.5 \%$ glucose, thiamine $(2 \mu \mathrm{g} / \mathrm{ml})$, and 16 $\mathrm{L}$-amino acids $(20 \mu \mathrm{g} / \mathrm{ml} \mathrm{each})$, excluding methionine, cysteine, leucine, and lysine. Ampicillin $(12 \mu \mathrm{g} / \mathrm{ml})$ or chloramphenicol $(10 \mu \mathrm{g} / \mathrm{ml})$ was added to the medium for growth of strains harboring a plasmid that carries the bla or cat gene, respectively.

\section{Protein labeling and immunoprecipitation}

Cells were grown in minimal medium, pulse-labeled with $\left[{ }^{35} \mathrm{~S}\right]$ methionine $(20 \mu \mathrm{Ci} / \mathrm{ml}, 1400 \mathrm{Ci} / \mathrm{mmole})$, and prepared for gel electrophoresis, as described (Yamamori and Yura 1980). Immunoprecipitation of proteins was essentially as described by Ito et al. (1986). In quantitative immunoprecipitation, logphase cells labeled with $\left[{ }^{35} \mathrm{~S}\right]$ methionine $(20 \mu \mathrm{Ci} / \mathrm{ml}, 1 \mu \mathrm{g} / \mathrm{ml})$ for two generations were mixed with wild-type cells labeled with $\left[{ }^{3} \mathrm{H}\right]$ leucine $(10 \mu \mathrm{Ci} / \mathrm{ml}, 52 \mathrm{Ci} / \mathrm{mmole})$ and $\left[{ }^{3} \mathrm{H}\right]$ lysine $(10$ $\mu \mathrm{Ci} / \mathrm{ml}, 88 \mathrm{Ci} / \mathrm{mmole}$ ) as internal reference to correct for recovery. After electrophoresis on SDS gels $(7.5 \%)$, bands for individual proteins were cut out, solubilized in NCS (Amersham) at $50^{\circ} \mathrm{C}$ for $2 \mathrm{hr}$, and the radioactivity was determined in a liquid scintillation counter. The ratio of ${ }^{35} \mathrm{~S} /{ }^{3} \mathrm{H}$ radioactivity for each protein was divided by that of total protein to obtain relative content of GroEL or DnaK.

\section{RNA analysis}

Bacterial RNAs were extracted and subjected to nuclease S1 protection analysis, essentially as described (Mori and Aiba

Table 3. E. coli $K-12$ strains

\begin{tabular}{|c|c|c|}
\hline Strain & $\begin{array}{l}\text { Name used } \\
\text { in text }\end{array}$ & Genetic characters \\
\hline MC4100 & WT & $\begin{array}{l}\mathrm{F}^{-} \text {araD } \Delta(\operatorname{argF}-1 a c) U 169 \text { rpsL } \\
\text { relA flbB deoC ptsF rbsR }\end{array}$ \\
\hline KY1601 & $\Delta r p o H$ & $\begin{array}{l}\text { MC4100 } \Delta r p o H 30:: \text { kan zhf50 :: Tn10 } \\
\quad\left(\lambda \mathrm{pF} 13-\text { PrpoD }{ }_{\mathrm{hs}}-\mathrm{lacZ}\right)\end{array}$ \\
\hline KY1603 & R40-1 & KY1601 suhX401 \\
\hline KY1606 & $\mathrm{R} 40-2$ & KY1601 suhX402 \\
\hline KY1607 & R40-3 & KY1601 suhX403 \\
\hline KY1612 & $\Delta r p o H$ & $\begin{array}{l}\text { Same as in KY1601 but } \\
(\lambda \mathrm{pF} 13-\text { PgroE-lacZ) }\end{array}$ \\
\hline KY1615 & R30 & KY1601 suhX301 \\
\hline KY1616 & R34 & KY1612 suhX341 \\
\hline KY1617 & R42-1 & KY1612 sihX302 suhY421 \\
\hline KY1618 & $\mathrm{R} 42-2$ & KY1612 suhX302 suhY422 \\
\hline
\end{tabular}


1985). In brief, double-stranded DNA fragments were labeled with $\left[\gamma^{32} \mathrm{P}\right]$ ATP by T4 polynucleotide kinase and mixed with RNAs $(40 \mu \mathrm{g})$, and hybridizations were performed at $45^{\circ} \mathrm{C}$ unless stated otherwise. After digestion with nuclease S1 (170 U), the protected DNAs were analyzed by urea $(8 \mathrm{M})-\operatorname{gel}(5 \%)$ electrophoresis.

\section{Acknowledgments}

We thank K. Ito for discussion, and C. Georgopoulos, R. Yano, and H. Nagai for plasmids or antiserum, and C.A. Gross for comments on the manuscript. This work was supported, in part, by grants from the Ministry of Education, Science, and Culture, Japan.

\section{Note added in proof}

Nucleotide sequence analysis indicated that an IS10-like element has been inserted into the groE heat shock promoter $1 \sim 30$ bp upstream of the transcription start site) on the R40-1 chromosome.

\section{References}

Bardwell, J.C.A. and E.A. Craig. 1984. Major heat shock gene of Drosophila and the Escherichia coli heat-inducible $d n a K$ gene are homologous. Proc. Nat. Acad. Sci 81: 848-852.

- 1987. Eukaryotic $M_{\mathrm{r}} 83000$ heat shock protein has a homologue in Escherichia coli. Proc. Natl. Acad. Sci. 84: $5177-5181$.

Carrascosa, J.L., J.A. Garcia, and M. Salas. 1982. A protein similar to Escherichia coli groEL is present in Bacillus subtilis. J. Mol. Biol. 158: 731-737.

Cowing, D.W., J.C.A. Bardwell, E.A. Craig, C. Woolford, R.W. Hendrix, and C.A. Gross. 1985. Consensus sequence for Escherichia coli heat shock gene promoters. Proc. Natl. Acad. Sci. 82: 2679-2683.

Ellis, J. 1987. Proteins as molecular chaperones. Nature 328: $378-379$.

Fayet, O., J.-M. Louarn, and C. Georgopoulos. 1986. Suppression of the Escherichia coli dnaA46 mutation by amplification of the groES and groEL genes. Mol. Gen. Genet. 202: 435-445.

Friedman, D.I., E.R. Olson, C. Georgopoulos, K. Tilly, I. Hershowitz, and F. Banuett. 1984. Interactions of bacteriophage and host macromolecules in the growth of bacteriophge $\lambda$. Microbiol. Rev. 48: 299-325.

Georgopoulos, C., K. Tilly, and S. Casjens. 1983. Lambdoid phage head assembly. In Lambda II (ed. R.W. Hendrix, J.W. Roberts, F.W. Stahl, and R.A. Weisberg|, pp. 279-304. Cold Spring Harbor Laboratory, Cold Spring Harbor, New York.

Goff, S.A. and A.L. Goldberg. 1985. Production of abnormal proteins in E. coli stimulates transcription of lon and other heat shock genes. Cell 41: 587-595.

Groat, R.G., J.E. Schultz, E. Zychlinsky, A. Bockman, and A. Matin. 1986. Starvation proteins in Escherichia coli: Kinetics of synthesis and role in starvation survival. $J$. Bacteriol. 168: 486-493.

Grossman, A.D., J.W. Erickson, and C.A. Gross. 1984. The htpR gene product of $E$. coli is a sigma factor for heat-shock promoters. Cell 38: 383-390.

Grossman, A.D., D.B. Straus, W.A. Walter, and C.A. Gross. 1987. $\sigma^{32}$ synthesis can regulate the synthesis of heat shock proteins in Escherichia coli. Genes Dev. 1: 179-184.

Iida, S., J. Meyer, and W. Arber. 1983. Prokaryotic IS elements. In Mobile genetic elements (ed. J.A. Shapiro). Academic Press, New York.
Ito, K., Y. Akiyama, T. Yura, and K. Shiba. 1986. Diverse effects of the malE-lacZ hybrid protein on Escherichia coli cell physiology. I. Bacteriol. 167: 201-204.

Jenkins, A.J., J.B. March, I.R. Oliver, and M. Masters. 1986. A DNA fragment containing the groE genes can suppress mutations in the Escherichia coli dnaA gene. Mol. Gen. Genet. 202: 446-454.

Krueger, J.H. and G.C. Walker. 1984. groEL and $d n a K$ genes of Escherichia coli are induced by UV irradiation and nalidixic acid in an $h t p R^{+}$-dependent fashion. Proc. Natl. Acad. Sci. 81: 1499-1503.

Landick, R., V. Vaughn, E.T. Lau, R.A. VanBogelen, J.W. Erickson, and F.C. Neidhardt. 1984. Nucleotide sequence of the heat shock regulatory gene of $E$. coli suggests its protein product may be a transcription factor. Cell 38: 175-182.

McMullin, T.W. and R. Hallberg. 1988. A highly evolutionarily conserved mitochondrial protein is structurally related to the protein encoded by the Escherichia coli cells groEL gene. Mol. Cell Biol. 8: 371-380.

Mori, K. and H. Aiba. 1985. Evidence for negative control of cya transcription by cAMP and cAMP receptor protein in intact Escherichia coli cells. J. Biol. Chem. 260: 14838-14843.

Neidhardt, F.C. and R.A. VanBogelen. 1981. Positive regulatory gene for temperature-controlled proteins in Escherichia coli. Biochem. Biophys. Res. Commun. 100: 894-900.

- 1987. Heat shock response. In Escherichia coli and Salmonella typhimurium (ed. F.C. Neidhardt). American Society for Microbiology, Washington, D.C.

Neidhardt, F.C., R.A. VanBogelen, and V. Vaughn. 1984. The genetics and regulation of heat-shock proteins. Annu. Rev. Genet. 18: 295-329.

Neidhardt, F.C., T.A. Phillips, R.A. VanBogelen, M.W. Smith, Y. Georgalis, and A.R. Subramanian. 1981. Identity of the B56.5 protein, the A-protein and the groE gene prouct of Escherichia coli. J. Bacteriol. 145: 513-520.

Paek, K.-H. and G.C. Walker. 1987. Escherichia coli dnaK null mutants are inviable at high temperature. I. Bacteriol. 169: 283-290.

Pelham, H.R.B. 1986. Speculations on the functions of the major heat shock and glucose-regulated proteins. Cell 46: $959-961$.

Pushkin, A.V., V.L. Tsuprum, N.A. Solovjeva, V.V. Shubin, Z.G. Evstigneeva, and W.L. Kretovich. 1982. High molecular weight pea leaf protein similar to the groE protein of Escherichia coli. Biochim. Biophys. Acta 704: 379-384.

Reuter, S.H. and L. Shapiro. 1987. Asymmetric segregation of heat-shock proteins upon cell division in Caulobacter crescentus. J. Mol. Biol. 194: 653-662.

Schlesinger, M.J., M. Ashburner, and A. Tissieres, eds. 1982. Heat shock: From bacteria to man, Cold Spring Harbor Laboratory, Cold Spring Harbor, New York.

Skelly, S., T. Coleman, C.-F. Fu, N. Brot, and H. Weissbach. 1987. Correlation between the $32-\mathrm{kD} \sigma$ factor levels and in vitro expression of Escherichia coli heat shock genes. Proc. Natl. Acad. Sci. 84: 8365-8369.

Straus, D.B., W.A. Walter, and C.A. Gross. 1987. The heat shock response of Escherichia coli is regulated by changes in the concentration of $\sigma^{32}$. Nature 329: 348-351.

Subramanian, A.R., C. Haase, and M. Giesen. 1976. Isolation and characterization of a growth-cycle-reflecting high-molecular-weight protein associated with Escherichia coli ribosomes. Eur. J. Biochem. 67: 591-601.

Taylor, W.E., D.B. Straus, A.D. Grossman, Z.F. Burton, C.A. Gross, and R. Burgess. 1984. Transcription from heat-inducible promoters causes heat shock regulation of the sigma subunit of $E$. coli RNA polymerase. Cell 38: 371-381. 
Tilly, K., H. Murialdo, and C. Georgopoulos. 1981. Identification of a second Escherichia coli groE gene whose product is necessary for bacteriophage morphogenesis. Proc. Natl. Acad. Sci. 78: 1629-1633.

Tobe, T., K. Ito, and T. Yura. 1984. Isolation and physical mapping of temperature-sensitive mutants defective in heatshock induction of proteins in Escherichia coli. Mol. Gen. Genet. 195: 10-16.

Travers, A.A. and H.A.F. Mace. 1982. The heat shock phenomenon in bacteria - A protection against DNA relaxation? In Heat shock: From bacteria to man (ed. M.J. Schlesinger, M. Ashburner, and A. Tissieres). Cold Spring Habor Laboratory, Cold Spring Harbor, New York.

Vogel, H.J. and D.M. Bonner. 1956. Acetylornithinase of Escherichia coli: Partial purification and some properties. I. Biol. Chem. 218: 97-106.

Wada, M. and H. Ichikawa. 1984. Participation of Escherichia coli K-12 groE gene products in the synthesis of cellular DNA and RNA. I. Bacteriol. 157: 694-696.

Yamamori, T. and T. Yura. 1980. Temperature-induced synthesis of specific proteins in Escherichia coli: Evidence for transcriptional control. J. Bacteriol. 142: 843-851.

1982. Genetic control of heat-shock protein synthesis and its bearing on growth and thermal resistance in Escherichia coli K-12. Proc. Natl. Acad. Sci. 79: 790-794.

Yano, R., M. Imai, and T. Yura. 1987. The use of operon fusions in studies of the heat-shock response: Effects of altered sigma 32 on heat-shock promoter function of Escherichia coli. Mol. Gen. Genet. 207: 24-28.

Yura, T., T. Tobe, K. Ito, and T. Osawa. 1984. Heat shock regulatory gene (htpR) of Escherichia coli is required for growth at high temperature but is dispensable at low temperature. Proc. Natl. Acad. Sci. 81: 6803-6807.

Zhou, Y.-N., N. Kusukawa, J.W. Erickson, C.A. Gross, and T. Yura. 1988. Isolation and characterization of Escherichia coli mutants that lack the heat shock sigma factor $\left(\sigma^{32}\right)$. J. Bacteriol. (in press). 


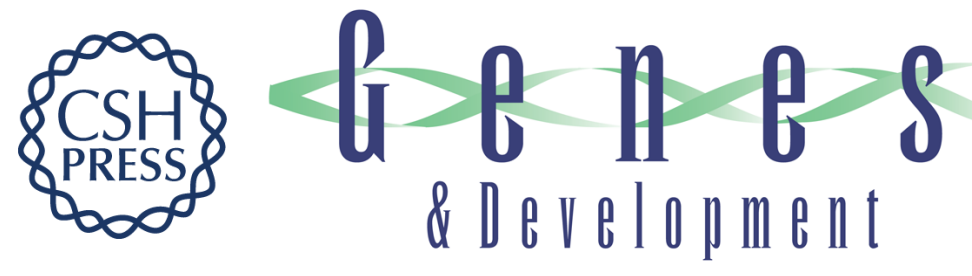

\section{Heat shock protein GroE of Escherichia coli: key protective roles against thermal stress.}

N Kusukawa and T Yura

Genes Dev. 1988, 2:

Access the most recent version at doi:10.1101/gad.2.7.874

References This article cites 36 articles, 19 of which can be accessed free at:

http://genesdev.cshlp.org/content/2/7/874.full.html\#ref-list-1

License

Email Alerting Receive free email alerts when new articles cite this article - sign up in the box at the top Service right corner of the article or click here.

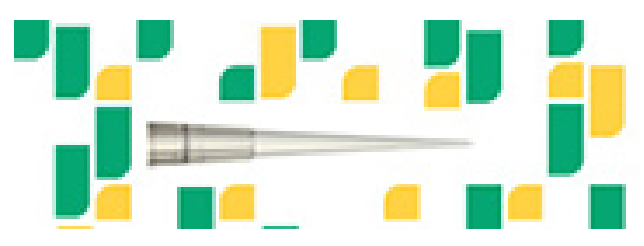

Focused on your science. 